\title{
Jordanian Evidence for the Pay-Performance Relation
}

\author{
Imad Zeyad Ramadan ${ }^{1}$ \\ ${ }^{1}$ Finance Department, Applied Science Private University, Amman, Jordan \\ Correspondence: Imad Zeyad Ramadan, Associate Professor, Finance Department, Applied Science Private \\ University, P.O. Box 166, Amman, Jordan. E-mail: Prof_imad67@yahoo.com
}

Received: December 8, 2012

Accepted: December 26, 2012

Online Published: January 31, 2013

doi:10.5539/ibr.v6n3p174

URL: http://dx.doi.org/10.5539/ibr.v6n3p174

\begin{abstract}
The intention of the study is to test the pay-performance relation for the Jordanian manufacturing firms listed on the Amman Stock Exchange during the period 2000-2011. Using two regression methods; the Ordinary Least Square Method, and the Fixed Effect Method, three models were tested. All three models that have been tested concluded a positive and significant impact of the CEO remuneration on the Jordanian manufacturing firms' performance. Another finding of the study, that is, due to specific-characteristics of each of the companies, the impact of the remuneration varies among the Jordanian Industrial Firms in the magnitude of the impact, and consistent in the direction of the impact. These findings are compatible with the say that the CEO remuneration have a significant role in mitigating the agency problem by granted reasons for CEOs perform their tasks to the magnification of owner's wealth, and that the remuneration should reflect and suit firm's performance. Also these results support the view that connecting the wealth of CEO to the performance of the firm can bring into line the interests of owners and those of CEO, and thus, helps improving the firm's performance.
\end{abstract}

Keywords: CEO compensation, performance, Jordan firms

\section{Introduction}

In this study we examined the relationship between CEO (Chief Executive Officer) remuneration and the corporation performance in Jordan, and up to the knowledge of the researcher, this is the first study of its type in Jordan with that goal. Many applied studies in the developed countries have been done to examine this relationship. One example is the work of Girma et al. (2007), which studied the effect of Cadbary reforms in the field of the CEO remuneration in UK companies, and concluded that the relationship between CEO compensation and the corporation performance was weak in terms of statistical significance. Gregg et al. (2005) concluded the same weak relationship in their study. Ozkan (2007) used the sum of the CEO compensations in the major British companies during the fiscal year 2003 - 2004 concluded that there is no significant relationship between the CEO compensations and the performance of the UK corporations.

In the other hand, Sigler (2011) found a proportional relationship with a statistical significance between the sum of CEO compensations and the performance of the American industrial companies after the adoption of Sarbanes Oxley Act.

Jensen and Murphy (2010) concluded that the remuneration of the CEO in most of the public USA firms was with no effect on their performance. Aggrwal (1999) detected a relationship between the CEO remuneration and the profitability, and concluded that the sensitivity of the change in wealth of the firm owners as a result of the change of the CEO compensations was (0.01452).

Based on the above review, the goal of this study is to try to highlight the assumed relationship between CEO remuneration and the firm's performance for the manufacturing listed Jordanian company.

In the Empirical Analysis, the CEO compensation was expressed as the sum of money compensations added to the basic salaries instead of the stock options and long-term incentive plans, because the latter is not used in Jordan, where the performance of the corporation, is expressed in the study, as the Return on Assets. Also the study has employed a group of Control Variables that represent the Corporation Governance Variables which have been known to have effects on the corporate performance by many studies (e.g. Diamond \& Verrecchia, 1991; Leuz \& Verrecchia, 2000; Verecchia, 2001; Bushman \& Smith, 2001).

A key effort of this study is that it tests the relationship in developing countries rather than developed countries, according to the knowledge of the researcher, this relationship has not been tested in Jordan, and thus contributes 
the literature by adding new evidence for the reality of the situation in these countries.

Additionally, the study control for a set of corporate governance; CEO duality, board size, board independence, as the previous literature suggested that the corporate governance mechanisms alleviate the problem of agency and thus improve the company's performance.

Finally, different from other researcher, we used the Fixed-Effect estimation method (FEM) to test for the probability that the effect of CEO compensation on the firm's performing varies among Jordanian manufacturing companies due to unobserved firm-specific characteristics.

The Experimental Findings of this study suggested a positive and significant relation between the CEO remuneration measured by the sum of the base salary and cash remuneration and the Jordanian industrial firm's performance measured by the return on total assets (ROA).

Another finding of the study is the positive and significant effects of CEO remuneration on the firms' performance differ among the Jordanian industrial firms due to the unobserved individuality.

The frame of the paper is planned as follows; part 2 discusses related literatures part 3 provides data and methodology, part 4 includes empirical results, and lastly part 5 ends with a conclusion.

\section{Related Literature}

Even though there is a wide range of preceding searches examining the association between CEO remuneration and the performing of the firm, these studies have been performed on companies operating in developed financial markets, and in countries characterized by its strong economy, such as American and European companies. Jensen and Murphy, (1990), Gibbons and Murphy (1992), and Paul and Nancy (1994), all suggested significantly positively association between total remuneration and corporate profitability in the US companies.

Gerhart and Milkovich (1990) tested the impact of compensations on a company's return by dividing the compensations to three levels: Short-term, Long-term, and base wages, the study found that short-term and long-term compensations associated positively with the company's performance, expressed as return on assets (ROA), while the basic salary had no significant effect on the corporate performance. Moreover the study of Hayes and Schaefer (2000) investigated the association between firm's profitability and remuneration, and found that the remuneration has a direct relation with return on equity, a proxy of corporate performance. Fich and Shivdasoni (2005) concluded that the stock-based compensation and abnormal return are related positively and significantly in US Company. Murphy (1999) concluded a strong significant association between cash remuneration and corporate revenues, and that the relation holds for all industries in US company.

Baptists (2010), investigated the CEO pay-performance in France, taken into account the total remuneration, and used the accounting and market measures for performance. The study concluded a weak and significant relation between ROA and total remuneration, and no proof of a significant association between historical performance and remuneration in French companies.

Eddy Junarsin (2011) examines the relation between the compensation and corporate performance using four measures for performance: ROA; EPS; MB; return, and the five kinds of remuneration: Total remuneration; Wages; Bonus; Constrained Stock Grant; and Options. The study concluded that total remuneration is directly associated with the corporate profitability, and the relation is stronger for top paid CEO, while the ratio of base wages to total remuneration is negatively associated with corporate profitability, meaning that the base wages as a type of CEO remuneration is less important in high-performing companies.

Main et al. (1996) tested the relation between total remuneration and the performance in the absence of the corporate governance variables. The study concluded a weak relation in the UK companies. Also Gregg et al. (2005) came to the same conclusion.

A study of Giorgio Brunella et al. (2001) suggested a weak relation between compensation and the Italian firm's profitability, and that the relation between CEO compensation and the firm's profitability is stronger: in foreign-owned firms, multinational firms, and listed firms.

Ozkan (2007) tested the effect of corporate governance on the CEO pay's for UK companies, and found no significant relationship between CEO remuneration and corporate performance, while Board Of Directors (BOD) size and ownership structure, as determinants of the corporate governance, of the UK companies explains significantly the variation in the compensation.

\section{Data and Methodology}

This paper adopts the quantitative research approach by utilizing unbalanced pooled cross-sectional time series for all 77 manufacturing companies listed at ASE within the time horizon 2000-2011. 
Two regression methods were adopted; the Ordinary Least Square (OLS) to test for the potential pay-performance relation, and the Fixed Effect Regression Method (FEM) to test for the possibility that the potential effect of the CEO remuneration on the firm's performance differ among the Jordanian industrial Firms.

As for the statistical test, the return on asset (ROA) was appointed to be the dependent variable in the econometric model of the study, while the cash compensation as proxy of the CEO compensation was appointed as the independent variable.

\subsection{Control Variables}

As for the control variables, we control the pay-performance relation with a set of the corporate governance variables; CEO duality, board size, board independence.

\subsubsection{CEO Duality}

The disconnection parting of the posts of Chairman of the BOD and CEO is one of the most important indicators of the strength of corporate governance that increase the efficiency of the BOD (Fama \& Jensen, 1983; Cadbury, 1992). According to the agency theory, which assumes that managers are opportunists, the disconnection parting of the posts of Chairman of BOD and CEO improves the efficiency of corporate governance and shareholder control over CEO rulings, and therefore improves the performing of the company by reducing agency costs.

Shivdasani and Zenner (2004) concluded that granting the CEO duties to the BOD Chairman makes it harder for the BOD to replace the CEO in the case of poor performance. Goyal and Park (2002) concluded that the combination of the two posts reduces flexibility, efficiency and speed of the BOD in treating the decline in the performance of the company.

We proxy for the CEO duality by the dummy-variable (D_DUL), D_DUL takes value of 1 if there is a separation between the two posts, otherwise 0

\subsubsection{Board Size}

Even though size of the BOD has a direct effect on the quality of corporate governance, no consensus on the optimal number of the BOD that can perform his duties as the best in terms of management of the company's activities and performance control. Studies on the effect of the size of the BOD concluded that the larger the BOD members, the less efficiency the board is in managing the company and oversight of its activities, due to the difficulty of; communication, coordination and variances in views between members, (Hermalin \& Weishach, 2003).

The study of Yermack, (1996) has concluded a negative relation between the BOD size and company's performance, and as the BOD size becomes larger, it becomes slower in making decisions.

The median of the board size was calculated for all the companies for each year of the study. We proxy for the board size by the dummy-variable (DBRD_SIZ), DBRD_SIZ takes value of 1 if the BOD size of $i^{\text {th }}$ firm at $\mathrm{t}^{\text {th }}$ time is greater than all companies median at time $t$, otherwise 0 .

\subsubsection{Board Independence}

The independence of the BOD considered one of the main pillars of the theory of agency (Fama \& Jensen, 1983). There is almost unanimous in the literature of finance that the escalation in the proportion of independent members in the BOD, escalate the efficiency of the BOD in the oversight of management (Morck \& Nakamura, 1994; Kaplan \& Minton, 1994; Bhagat \& Black, 2002), and increases the possibility that the BOD to replace weak CEO.

Solomon et al. (2003) and Tsui and Gul (2000) concluded that increasing the proportion of the independent members in the BOD plays a critical part for the benefit of investors, especially small investors.

The independence of the BOD was expressed through the proportion of external members in the BOD to the total members of the BOD of each of the companies in the study for each year of study. We proxy for the board independence by the dummy-variable (DBRD_IND), DBRD_IND takes value of 1 if the proportion of external members in BOD to the total members of BOD of the $\mathrm{i}^{\text {th }}{ }^{-}$firm at $\mathrm{t}^{\text {th }}$ time is greater than the median of all companies at time $\mathrm{t}$, otherwise 0 .

\subsection{Econometric Model}

To test the pay-performance relation, the general model has the form of:

$$
\text { Firm's performance }=f(C E O \text { compensation, Corporate Governance) }
$$

This equation suggests that the performance is a function of the CEO pay's and the corporate governance. The 
econometric model of the study will be presented as follows:

$$
R O A_{i t}=\alpha+\beta_{1} \text { CEO_COM } i t+\sum_{j=1}^{n} \gamma_{j} \text { control } \text { variables }_{i t}+\varepsilon_{i t}
$$

Whereas, $R O A_{i t}$ is the proxy of the firm's performance for $i^{t h}$ cross-sectional firm at $t^{t h}$ time, with $i=$ $1,2,3, \ldots, 77, t=1,2,3, \ldots \ldots, 11, \alpha$ constant, $\beta$ unknown parameter for the independent variable the CEO compensation to be estimated, $n=1,2,3$ the count of the control variables, $\gamma$ unknown parameter of the control variables, which includes the specific characteristics of the firm's corporate governance to be appraised.

The econometric model can be rewritten using corporate governance variables as follows:

$$
R O A_{i t}=\alpha+\beta_{1} C E O_{-} C O M_{i t}+\gamma_{1} D_{-} D U L_{i t}+\gamma_{2} D B R D \_S I Z_{i t}+\gamma_{3} D B R D_{-} I N D_{i t}+\varepsilon_{i t}
$$

Where, $\gamma^{\prime} s$ unknown coefficients of the control variables to be appraised, $D_{-} D U L$ dummy-variable as proxy of the CEO duality, $D B R D_{-} S I Z$ dummy-variable as proxy of the board size, $D R B D_{-} I N D$ dummy-variable as proxy of the board independent.

\subsection{Hypothesis Elaboration}

Based on the theory of agency, the agency problem expresses the conflict of interest between CEO and the owners. CEO, acting as the agent for the owners, is assumed to make decisions in the owner's best benefits. But, it is in the CEO's own best interest to consider his own interests. While it is not likely to exclude the agency problem completely, the $\mathrm{CEO}$ can be motivated to act in the owners best interests through remuneration, such as performance-based remuneration. This paper aims to investigate the possible relationship between the CEO remuneration and the performance, and to achieve this goal, the following hypothesis will be tested:

$H_{01}$ : There is no statistically significant association between the CEO remuneration and the firm's performance for the Jordanian manufacturing firms listed at ASE.

$H_{01}$ can be rewritten mathematically as:

$$
H_{01}: \beta=0,|\operatorname{sig}<0.05|
$$

Whereas, $\beta$ the regression coefficients of the CEO remuneration on the company's performance, if Sig. $\leq 5 \%$, we will reject the $H_{0}$, if not, there isn't enough cause to reject it.

To test the possibility that the potential effect of the COE remuneration on the corporate performance differ among the cross-sectional Jordanian Industrial firms we tested the following hypothesis:

$H_{02}$ : There are no statistically significant differences of the COE remuneration effect on the performance of Jordanian manufacturing firms listed at ASE.

$H_{02}$ can be rewritten mathematically as:

$$
H_{02}: \varphi_{1}=\varphi_{2}=\varphi_{3}=\cdots=\varphi_{i},|\operatorname{sig}<0.05|
$$

Whereas, $\varphi_{i}$ are the regression coefficients of the interaction variable ( $D_{i_{-}}$COE_COM) between the cross-sectional firm's dummy variable $\left(D_{i}\right)$ and the CEO remuneration variable (CEO_COM) with $i=1,2$, $3, \ldots, 77$. If at least one of the regression coefficients of the interaction variables has a $\mathrm{Sig}$. $\leq 5 \%$, we will reject the $H_{02}$, otherwise accept it.

\section{Experimental Findings}

The findings of testing the pay-performance relation for the Jordanian industrial companies are reported in the following part.

\subsection{Correlation Analysis Findings}

Table 1 presents the Pearson correlation coefficients between the variables used in the econometric model of the study. The results show that the CEO_COM associated positively significantly with the corporate performance, indicating that the greater are the CEO compensations the better is the corporate performance.

The result is compatible with the view that the remuneration should be based on merit, so that the preeminent person gets the best positions and assume greater responsibilities, which comes with appropriate rewards.

Table 1 also shows that the corporate performance and the board size are significantly negatively associated; indicating that increasing the board size will reduce the efficiency of the board, which is reflected negatively on the company's performance. Also the Table shows that the separation between the posts of Chairman and CEO positively correlated with the performance of the company. 
Table 1. Pearson correlation matrix

\begin{tabular}{lllllll}
\hline Variable & & ROA & CEO_COM & DRBD_SIZ & D_DUAL & DBRD_IND \\
\hline ROA & Coefficient & 1 & $.261^{* *}$ & $-.174^{* *}$ & $.067^{*}$ & -.046 \\
& Sig. & & .000 & .000 & .046 & .174 \\
CEO_COM & Observations & 879 & 879 & 879 & 879 & 879 \\
& Coefficient & $.261^{* *}$ & 1 & $.332^{* *}$ & $-.182^{* *}$ & -.035 \\
& Sig. & .000 & & .000 & .000 & .304 \\
DRBD_SIZ & Observations & 879 & 879 & 879 & 879 & 879 \\
& Coefficient & $-.174^{* *}$ & $.332^{* *}$ & 1 & $-.138^{* *}$ & .028 \\
& Sig. & .000 & .000 & & .000 & .413 \\
D_DUAL & Observations & 879 & 879 & 879 & 879 & 879 \\
& Coefficient & $.067^{*}$ & $-.182^{* *}$ & $-.138^{* *}$ & 1 & $.146^{* *}$ \\
& Sig. & .046 & .000 & .000 & & .000 \\
DBRD_IND & Observations & 879 & 879 & 879 & 879 & 879 \\
& Coefficient & -.046 & -.035 & .028 & $.146^{* *}$ & 1 \\
& Sig. & .174 & .304 & .413 & .000 & 879 \\
\hline
\end{tabular}

Notes: ** *; Significant at $0.01,0.05$ level respectively. Definitions and measures of the variables are presents at appendix 1.

The results are compatible with the view that the separation of the posts and a small BOD works towards increasing the efficiency of the BOD in the control of the CEO, which will reflect positively on the company's performance.

Surprisingly, the Table shows that the independence of the BOD is not significantly associated with the company's performance at the 0.05 level of significance.

\subsection{Regression Analysis Findings}

Three regression models were utilized, and the regression analysis findings are presented in tables 2,3 , and 4 . In Table 2 model 1, the pay-performance relation was tested with the nonexistence of the corporate governance variables. In Table 3 model 2, we controlled with the corporate governance variables, while in Table 4 model 3 the differential slope coefficient dummies method were used to permit the slope parameter regression to differ between firms, to test for the possibility that the effect of the remuneration on the performance varies among Jordanian industrial companies due to the different in the internal specific-characteristics.

Table 2 report the estimated parameter of the unbalanced pooled cross-sectional time series panel regression for model 1. The table shows a positive effect of the CEO_COM on the corporate performance at significant level less than 0.01 . This result is compatible with the view that top CEO reward better able to generate profits for their companies, and thus improve its performance.

Table 2 also shows that with the nonexistence of the corporate governance variables, the CEO remuneration by itself was able to explain almost $7 \%$ of the change in the corporate performance (Adjusted R-Square $=0.067$ ), and that the sensitivity of the change in the performance of the company as a result of the change in CEO remuneration is .0097 at a significant 0.01 .

Table 2. Regression analysis finding for model 1

\begin{tabular}{ll}
\hline Variable & Coefficient \\
\hline Constant & 3.089 \\
CEO_COM & $.0097^{* *}$ \\
& 8.009 \\
& .000 \\
Adjusted R-Square & 0.067 \\
df Regression & 1 \\
Residual & 877 \\
Total & 878 \\
F. & 64.143 \\
Sig. & .000 \\
\hline
\end{tabular}

Notes: Dependent variable: ROA a proxy of the performance, First line regression coefficient, Second line t value, Third line sig. (2-tail). **, *; significant at $0.01,0.05$ level respectively. Variables definitions are listed at appendix 1. 
In model 2, Table 3 shows that after controlling with the corporate governance the explanatory power of the model 2 has been improved to become 9.3\%, which indicates that model 2 is better than model 1 to explain the pay-performance relation. The results appear in Table 3 shows that the impact of the CEO remuneration on the company's performance remained positive and statistically significant at a significant level less than 0.01 , and that the sensitivity of the change in the performance of the company as a result of the change in CEO remuneration with the existence of the control variables is .0128 at a significant level 0.01 .

Another result shown by Table 3, that the association between BOD size and the company's performance is a statistically significant inverse relationship, suggesting that the increase in the size of the Board could lead to a decrease in the efficiency of the Board, and thus, adversely impact the performance of the company.

Table 3 also shows that the separation between the Chairman of the BOD and the CEO duties leads to a better performance for the Jordanian industrial companies, but unexpectedly, this result was statistically insignificant at 0.05 significant levels.

Table 3. Regression analysis finding for model 2

\begin{tabular}{ll}
\hline Variable & Coefficient \\
\hline Constant & 8.945 \\
CEO_COM & $.0128^{* *}$ \\
& 6.476 \\
DBRD_SIZ & .000 \\
& $-.921^{* *}$ \\
& -2.869 \\
D_DUAL & .004 \\
& .321 \\
DBRD_IND & .204 \\
& .838 \\
Adjusted R-Square & -1.57 \\
df Regression & -1.21 \\
Residual & .226 \\
Total & 0.093 \\
F. & 4 \\
Sig. & 874 \\
\hline
\end{tabular}

Notes: Dependent variable: ROA a proxy of the performance, First line regression coefficient, Second line t value, Third line sig. (2-tail). **, *; significant at $0.01,0.05$ level respectively. Variables definitions are listed at appendix 1 .

Other unexpected result is that the independence of the Board of Directors adversely affect the performance of Jordanian industrial companies, this result also was not statistically significant at 0.05 significant levels.

By using the Fixed Effect Method (FEM) to allow the slopes of the parameter to vary between the Jordanian Industrial firms, Table 4 shows the variables that are not excluded from the analysis, due to their constancy or its missing correlation, and were statistically significant. It shows that the number of these variables is 15 which means that the pay-performance relation varies among the Jordanian Industrial companies due to the firm's internal specific-characteristics.

It is worth to note that the variation among the Jordanian firms is in the magnitude of the effect and not in the direction of the effect, where Table 4 shows that all parameter for the interaction variables were positive. This result supports what has been concluded earlier by using the Ordinary Least Square Method (OLS) in model 2 about the positive effect of the CEO compensation on the corporate performance for the Jordanian Industrial firms.

Table 4 shows another improvement in the explanatory power when using the FEM instead of the Ordinary Least Square Method (OLS), with the value of Adjusted R-Square rising to $11.8 \%$. 
Table 4. Differential Slope Coefficient for model $3^{*}$

\begin{tabular}{llll}
\hline Model 3 & Coefficients & $\mathrm{t}$ & Sig. \\
\hline (Constant) & 17.064 & 5.540 & .000 \\
D5_CEO_COM & .0091 & 2.252 & .025 \\
D15_CEO_COM & .0075 & 4.127 & .000 \\
D20_CEO_COM & .0109 & 2.905 & .004 \\
D28_CEO_COM & .0113 & 3.332 & .001 \\
D31_CEO_COM & .0031 & 2.111 & .035 \\
D34_CEO_COM & .0071 & 2.187 & .029 \\
D39_CEO_COM & .0129 & 3.629 & .000 \\
D42_CEO_COM & .0094 & 4.075 & .000 \\
D45_CEO_COM & .0012 & 2.349 & .019 \\
D51_CEO_COM & .0093 & 2.717 & .007 \\
D53_CEO_COM & .0200 & 2.159 & .034 \\
D63_CEO_COM & .0051 & 1.995 & .047 \\
D71_CEO_COM & .0131 & 2.426 & .015 \\
D75_CEO_COM & .0104 & 2.502 & .013 \\
D76_CEO_COM & .0087 & 2.600 & .009 \\
DBRD_SIZ &. .872 & -4.407 & .000 \\
D_DUAL & .712 & 1.285 & .199 \\
DBRD_IND & -1.03 & .973 & .331 \\
\hline Adjusted R-Square & .118 & & \\
df Regression & 45 & & \\
Residual & 833 & & \\
Total & 878 & & \\
F. & 2.483 & & \\
Sig. & .000 & & \\
\hline
\end{tabular}

Notes: * 45 interaction variable out of the 77 were auto-excluded from the Fixed Effect analysis either because interaction variables are constants or have missing correlations, for the remaining 32 interaction variables only the results that are statistically significant were reported. Dependent variable: ROA a proxy of the performance, Di_CEO_COM; the interaction variable between the $i^{\text {th }}$ company dummy variable (Di) and the CEO compensation variable (CEO_COM). Variables definitions are listed at appendix 1.

Based on the above, and that's where: $\beta_{C E O \_C O M} \neq 0, \mid$ Sig. $<0.05 \mid$ we reject the $H_{01}$ and accept the alternative hypothesis which includes that there is a statistically significant association between the CEO remuneration and the firm's performance for the Jordanian industrial companies. And also because: $\varphi_{5} \neq \varphi_{15} \neq \varphi_{20} \neq \varphi_{28} \neq$ $\varphi_{31} \ldots \mid$ sig $<0.05 \mid$ we reject the $H_{02}$ and accept the alternative hypothesis which includes that there is a statistically significant differences of the COE remuneration effect on the performance of the Jordanian industrial companies.

\section{Conclusion}

The intention of the study is to test the pay-performance relation for the Jordanian manufacturing firms listed on the Amman Stock Exchange during the period 2000-2011. Using two regression methods; the Ordinary Least Square Method, and the Fixed Effect Method, three models were tested. All three models that have been tested concluded a positive and significant impact of the CEO remuneration on the Jordanian manufacturing firms' performance.

Another finding of the study, that is, due to specific-characteristics of each of the companies, the impact of the remuneration varies among the Jordanian Industrial Firms in the magnitude of the impact, and consistent in the direction of the impact.

These findings are compatible with the say that the CEO remuneration have a significant role in mitigating the agency problem by granted reasons for CEOs perform their tasks to the magnification of owner's wealth, and that the remuneration should reflect and suit firm's performance.

Also these results support the view that connecting the wealth of CEO to the performance of the firm can bring into line the interests of owners and those of CEO, and thus, helps improving the firm's performance.

\section{References}

Aggarwal, R. K., \& Samwick, A. A. (1999). Executive compensation, strategic competition and relative performance evaluation: Theory and evidence. Journal of Finance, 54, 1999-2043. http://dx.doi.org/10.1111/0022-1082.00180 
Baptista, M. (2010). CEO Compensation and Firm Performance in France. (HEC Paris Thesis). Retrieved from $\mathrm{http} / / /$ www.professionsfinancieres.com/docs/2011104134_17--ceo-compensation-and-firm-performance-infrance.pdf

Bhagat, S., \& Black, B. (2002). The non-correlation between board independence and long-term firm performance. Journal of Corporation Law, 27, 231-73.

Brunello, G., Graziano, C., \& Parigi, B. (2001). Executive compensation and firm performance in Italy. International Journal of Industrial Organization, 19(1-2), 133-161. http://dx.doi.org/10.1016/S0167-7187(99)00026-0

Bushman, R. M., \& Smith, A. J. (2001). Financial Accounting Information and Corporate Governance. Journal of Accounting and Economics, 32, 237-333. http://dx.doi.org/10.1016/S0165-4101(01)00027-1

Cadbury Report. (1992). The Report of the Committee on the Financial Aspects of Corporate Governance. The journal of finance, $\operatorname{LVII}(1)$.

Diamond, D., \& Verrecchia, R. (1991). Disclosure, Liquidity, and the Cost of Capital. Journal of Finance, 46, 1325-1359. http://dx.doi.org/10.1111/j.1540-6261.1991.tb04620.x

Fama, E. F., \& Jensen, M. C. (1983). Separation of ownership and control. Journal of Law \& Economics, 26(2), 301-26. http://dx.doi.org/10.1086/467037

Fich, E. M., \& Shivdasani, A. (2005). The impact of stock-option compensation for outside directors on firm value. Journal of Business, 78, 2229-2254. http://dx.doi.org/10.1086/497048

Gerhart, B., \& Milkovich, G. T. (1990). Organizational differences in managerial compensation and financial performance. Academy of Management Journal, 33, 663-691. http://dx.doi.org/10.2307/256286

Gibbons, R., \& Murphy, K. J. (1992). Optimal incentive contracts in the presence of career concerns: Theory and evidence. The Journal of Political Economy, 100, 468-505. http://dx.doi.org/10.1086/261826

Girma, S., Thompson, S., \& Wright, P. (2007). Corporate Governance Reforms and Executive Compensation. The Manchester School, 75(1), 65-81. http://dx.doi.org/10.1111/j.1467-9957.2007.01003.x.

Goyal, V., \& Park, C. (2002). Board leadership structure and CEO turnover. Journal of Corporate Finance, 81, 49-66. http://dx.doi.org/10.1016/S0929-1199(01)00028-1.

Gregg, P., Jewell, S., \& Tonks, I. (2005). Executive Pay and Performance in the UK 1994 - 2002. working paper, XFi Centre for Finance and Investment.

Hayes, R. M., \& Schaefer, S. (2000). Implicit contracts and the explanatory power of top executive compensation for future performance. Rand Journal of Economics, 31, 279-293. http://dx.doi.org/10.2307/2601041.

Hermalin, B. E., \& Weisbach, M. S. (2003). Board of directors as an endogenously determined institution: a survey of the economic literature. Economic Policy Review, 9(1), 7-26.

Jensen, M. C., \& Murphy, K. J. (1990). Performance Pay and Top-Management Incentives. Journal of Political Economy, 98(2), 225-64. http://dx.doi.org/10.1086/261677

Jensen, M., \& Murphy, K. (2010). CEO incentives - It's not how much pay, but how. Journal of Applied Corporate Finance, 22, 64-76. http://dx.doi.org/10.1111/j.1745-6622.2010.00262.x

Joskow, P. L., \& Rose, N. L. (1994). CEO Pay and Firm Performance: Dynamics, Asymmetries, and Alternative Performance Measures. NBER Working Papers 4976, National Bureau of Economic Research, Inc.

Junarsin, E. (2011). Executive Compensation and Firm Performance: An Empirical Examinatio. European Journal of Economics, Finance and Administrative Sciences, 28, 163-179.

Kaplan, S. N., \& Minton, B. A. (1994). Appointments of outsiders to Japanese boards: determinants and implications for managers. Journal of Financial Economics, 36(2), 225-58. http://dx.doi.org/10.1016/0304-405X(94)90025-6

Leuz, C., \& Verrecchia, R. E. (2000). The Economic Consequences of Increased Disclosure. Journal of Accounting Research, 38, 91-124. http://dx.doi.org/10.2307/2672910

Main, B. G. M., Bruce, A., \& Buck, T. (1996). Total board remuneration and company performance. Economic Journal, 106, 1627-1644. http://dx.doi.org/10.2307/2235204

Morck, R., \& Nakamura, M. (1994). Banks and corporate control in Japan. Working Paper, University of 
Alberta, Edmonton. Retrieved from http://www.jstor.org/pss/222418

Murphy, K. J. (1999). Executive Compensation. In O. Ashenfelster \& D. Card (Eds.), Handbook of Labor Economics (Vol III, pp. 2485-2563). Amsterdam: North-Holland. http://dx.doi.org/10.1016/S1573-4463(99)30024-9

Ozkan, N. (2007). CEO Compensation and Firm Performance: An Empirical Investigation of UK Panel Data. http://dx.doi.org/10.2139/ssrn.1102703

Shivdasani, A., \& Zenner, M. (2004). Best practices in corporate governance: what two decades of research reveals. The Bank of American Journal of Applied Corporate Finance, 16(2/3), 29-37. http://dx.doi.org/10.1111/j.1745-6622.2004.tb00536.x

Sigler, K. J. (2011). CEO Compensation and Company Performance. Business and Economic Journal, 2011, 1-8.

Solomon, J. F., Lin, S. W., Norton, S. D., \& Solomon, A. (2003). Corporate Governance in Taiwan: Empirical Evidence from Taiwanese Company Directors. Corporate Governance: An International Review, 11(3), 235-248. http://dx.doi.org/10.1111/1467-8683.00321

Tsui, J., \& Gul, F. A. (2000). Corporate Governance and Financial Transparencies in the Hong Kong -Special Administrative Region of The People's Republic of China. Proceedings of the 2nd Asian Roundtable on Corporate Governance. Retrieved on March 25, 2004 from http://www.oecd.org/dataoecd/57/58/33919929.pdf

Verrecchia, R. (2001). Essays on Disclosure. Journal of Accounting and Economics, 32, 97-180. http://dx.doi.org/10.1016/S0165-4101(01)00025-8

Yermack, D. (1996). Higher market valuation of companies with a small board of directors. Journal of Financial Economics, 40(2), 185-211. http://dx.doi.org/10.1016/0304-405X(95)00844-5

\section{Appendix 1. Definition, Measure, Notation, and Expected Effect}

\begin{tabular}{|c|c|c|c|c|}
\hline & Variable & Measure & Notation & Expected Effect \\
\hline 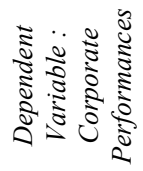 & Return on total assets & Net Profit before tax / Total Assets & $R O A$ & \\
\hline 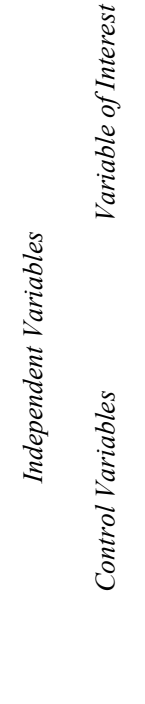 & $\begin{array}{l}\text { CEO Duality } \\
\text { Board Size }\end{array}$ & $\begin{array}{c}D_{-} D U L=\left\{\begin{array}{r}1 \text { separation between the two posts } \\
0 \text { otherwise }\end{array}\right. \\
\text { DBRD_SIZ }=\left\{\begin{array}{r}1 \text { if board size is greater than the } \\
\text { median of all companies } \\
0 \text { otherwise }\end{array}\right. \\
D B R D_{-} I N D=\left\{\begin{array}{c}1 \text { if proportion of external to } \\
\text { total members of board } \\
\text { directors } \text { is greater than the } \\
\text { median of all companies }\end{array}\right. \\
0 \text { otherwise }\end{array}$ & $\begin{array}{l}D \_D U L \\
D B R D \_S I Z\end{array}$ & + \\
\hline
\end{tabular}

